This work is licensed under a Creative Commons Attribution 4.0 International License.

Ovaj rad dostupan je za upotrebu pod licencom Creative Commons Imenovanje 4.0 međunarodna.

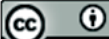

Igor GAJIN

UDK 82:004.1

Akademija za umjetnost i kulturu u Osijeku

82:366

Sveučilišta J. J. Strossmayera u Osijeku

DOI: https://doi.org/10.29162/ANAFORA.v7i2.6

Ulica kralja Petra Svačića 1/F

HR - 31000 Osijek

Prethodno priopćenje

gajinigor@gmail.com

Preliminary Communication

Primljeno 11. listopada 2020.

Received: 11 October 2020

Prihvaćeno 20. prosinca 2020.

Accepted: 20 December 2020

\title{
PRIČA ILI STORY KAO INSTRUMENT ILI MAŠNA (DE)HUMANIZACIJE ILI...
}

\section{Sažetak}

U znanosti i nastavi humanističke orijentacije sve je vidljivija favorizacija kvantifikacije, mjerljivosti, birokratizirane organizacije sadržaja i neopozitivizma, neo u smislu statističke obradivosti podataka, čime se evidentno prati logika računalne prezentacije informacija (umjesto znanja), a preko toga kapitalističko discipliniranje i nadziranje Gorzovog „nematerijalnog rada“. Internetom, filozofijom mreže, hipertekstom i hiperinformacijskim overloadom fragmentirana, disperzirana i dekontekstualizirana digitalna kultura zaziva u teoriji i praksi opozicijsku reakciju u pravcu reafirmacije klasične priče ili storytellinga kao arhetipske forme humaniziranja, organiziranja i osmišljavanja ljudskoga iskustva i znanja. Međutim, kada Amazon najavljuje da će autora honorirati onoliko koliko je stranica njegova teksta pročitano zahvaljujući aplikacijama za praćenje takvih rezultata, kada Christian Salmon otkriva storytelling kao novi instrument korporativnog businessa, kada storytelling postaje imperativ komercijalne književnosti i sredstvo industrijalizirane standardi- 
zacije književnosti, čemu se izlazi u susret trendom radionica za kreativno pisanje, pitanje je kome i čemu priča danas služi. Nije li prošlostoljetna (post)modernistička dekonstrukcija teksta i dezintegracija njegova ideologiziranog smisla bila onoliko humanija koliko se činila nečitljivom, za razliku od današnjeg zavođenja konzumerističkog objekta atrakcijama fabuliranja iz pera „dobavljača sadržaja“?

Ključne riječi: digitalizacija, STEM, storytelling, postmodernizam, kapitalizam

\section{Uvod}

Otpočevši 1994. godine s radom tek kao internetska knjižara, američka se tvrtka Amazon do danas razvila u „maloprodajnog i tehnološkog giganta“ (Erceg) te u „Vodeće(g) div(a) internetske trgovine“ (Bačić), istodobno zauzimajući i lidersku poziciju na tržištu e-knjiga i on line knjižarstva. Amazonove poslovne inicijative, ekonomski rast i tržišna dominacija „zahvaljujući“ sinergiji progresivne tehnološke invencije i beskrupulozne eksploatacije kontinuirano izazivaju strukturalne destabilizacije konvencionalnih regulacija u kulturnoj industriji, ali i općenito na tržištu rada, te nerijetko krajnje skandalozno redefiniraju konstitutivni sustav vrijednosti i praksi u tim poljima (Erceg).

Učinci takve Amazonove uloge nisu samo ekonomske ili strogo financijske prirode u smislu da u uobičajenim napetostima kapitalističke dinamike oko preraspodjele kapitala Amazon naveliko dovodi u pitanje opstanak konkurencije, posebice na izdavačkoj sceni, nego ekspanzijom do monopolističke koncentracije tržišnoga prostora kreira i uspostavlja nove, devastirajuće diktate u logici odnosa između ekonomske i kulturne dimenzije onih vrijednosti koje producira kulturna industrija. A jedan od vrhunaca takvih Amazonovih pohoda zacijelo je i odluka iz 2015. godine da se pisce plaća prema broju pročitanih stranica, što je postalo ostvarivo implementiranjem aplikacijskog brojčanika na uređaju Kindle za čitanje e-knjiga („Kad kultura postane biznis: Amazon će plaćati pisce po broju pročitanih stranica").

Naravno, odavno su prokazane ambicije kapitalističke ideologije da stvaralačku autonomiju u kulturi i umjetnosti podredi logici ekonomske koristi te ju u konačnici kolonizira mjerilima tržišnog režima kako bi kulturna i umjetnička ostvarenja postala resurs akumulacije financijskog kapitala. Utemeljiteljska kritika toga procesa ispisana je u kanonskom opusu Theodora Adorna, koji razvoj uvjeta za masovnu tehničku reprodukciju umjetničkoga djela, ekvivalentno konstataciji Waltera Benjamina o gubitku aure umjetničkoga djela u tom 
novonastalom poretku, prepoznaje kao komodifikaciju kulture i umjetnosti. Poraženo „filistarskim pogledom na umjetničko djelo“ (Adorno 42), umjetničko djelo „postaje stvar među stvarima“ (51), a uvođenje fetišističkog karaktera robe kao dominantnog načela kapitalističke kulture i u polje umjetničke autonomije čini od umjetnosti „pogon kojim upravlja profit, koji traje onoliko koliko je ta umjetnost rentabilna“ (52). Budući da kulturna industrija nije ništa drugo nego reprodukcija kapitalističkog sistema, umjetnost nadalje svojom produkcijskom „perfekcijom pomaže da se pređe preko činjenice da je već mrtva“ (52).

Iako je, dodaje P. Bourdieu, sada riječ „o pravoj strukturalnoj podređenosti, koja se veoma neravnomerno nameće različitim autorima u zavisnosti od njihove pozicije“ (78) kao „svedočanstvo najamničkog interesa ekonomskih i političkih ciljeva“ (308), ovaj autor u djelu Pravila umetnosti analizira kako je ipak moguće u presjeku tih dvaju polja, „u odnosima među različitim oblicima kapitala“ (306) kreirati zone neovisnosti. No, budući da je to takoreći svakodnevna borba, Bourdieu u tim napetostima ne vidi odavno svršenu kapitulaciju, poput Adorna, nego interakciju dinamičnog pregovaranja oko odnosa moći između te „dve ekonomske logike“ (204) kao „koegzistencije antagonizama“ (204) zbog suprotstavljenih zahtjeva.

Stoga su, prema Bourdieu, problematizirana polja „u svakom trenutku poprište između dva principa hijerarhizacije, heteronomnog, podesnog za one koji politički i ekonomski vladaju poljem (na primer 'buržoaska umetnost') i principa autonomije (na primer l'art pour l’art)“ (306), da bi potom zaključio kako situacija nije definitivna, nego je dobra ili loša za jedno ili za drugo polje ovisno o stupnju (ne)ravnoteže: „Stepen samostalnosti polja proizvodnje u kulturi se izražava u stepenu u kom je spoljna hijerarhizacija podređena principu unutrašnje“ (307).

\section{Zaposjedanje kulture industrijskom logikom}

Jasno je da se prijepori oko dominacije kapitalističkog režima u prostoru umjetnosti te u kulturnoj sferi individualne i kolektivne egzistencije ne odnose samo na problem preuzimanja i profaniranja gotovih kulturnoumjetničkih ostvarenja kao objekata tržišne cirkulacije kako bi se priključili ekonomiji robne razmjene za konzumerističke nagone potrošačkoga društva, nego je problematika postala s emergencijom kapitalističke kulture strukturalno dublja u smislu da se logika industrijske proizvodnje, logika ekonomično simplificirane tipizi- 
ranosti radi omasovljene hiperprodukcije robe, uvela u genezu umjetničkoga stvaralaštva, koje sada industrijaliziranom shematičnošću generira reproduktivnu umjetnost konfekcijskoga karaktera, danas „cijenjenu“ kao popularna kultura s obzirom na to da se svojom emergencijom, a potom i dominacijom, temeljenoj na masovnoj popularnosti, etablirala u kulturni identitet postmodernog društva.

Prenoseći nam jednu od uobičajenih definicija da je „popularna kultura proizvedena tehnikom masovne industrijske proizvodnje, a s ciljem da na masovnom tržištu ostvari profit" (Crnobrnja 94). Stanko Crnobrnja ujedno nam prezentira i ključne strukturalne analogije između industrijske organizacije i popkulturne produkcije, kao i posljedice popkulturne modeliranosti industrijskom racionalizacijom proizvodnog procesa:

Masovna proizvodnja i njene tehnološke zakonitosti ogledaju se, pre svega, u sledećim odlikama:

a) pokretna proizvodna traka,

b) podela i specijalizacija rada,

c) stroga fazna organizacija stepena proizvodnje,

d) veliki broj (količina) istovetnih proizvoda.

Ove odlike, karakteristične za organizaciju industrijske proizvodnje, obeležavaju i proizvodnju masovne kulture, kao i sve medije masovne kulture, dajući im na taj način posebne karakteristike, analogne masovnoj industrijskoj proizvodnji (...). Industrijski obrazac proizvodnje počinje da se primenjuje i na produkciju kulturnih sadržaja (...).

Od tog momenta, u proizvodnji kulturne „robe“ ističu se tri osnovne karakteristike:

1. standardizacija,

2. princip formule,

3. ponavljanje.

Ove karakteristike u proizvodnji kulturne „robe“ nastaju kao posledica proizvodnje na pokretnoj, industrijskoj traci. (95)

Takvom integracijom kulturne i umjetničke sfere s nadređenom logikom racionalizirane industrijske organizacije rada ujedno se ostvaruje i efikasnost discipliniranja, 
što rezultira hegemonijskim pristankom autorstva na reprodukciju estetike i poetičkih struktura zadanih dominantnim kodovima, $u$ konačnici i interiorizacijom tih obrazaca kao vlastitoga kulturnoga identiteta. A ako se autorska individualnost baš i inati, pismo mu se marginalizira i isključuje, doslovno odbacuje instrumentaliziranim ukusom publike, tako da je riječ o mehanizmu zatvorenog kruga koji tendira osiromašujućem sužavanju kreativnog prostora i inducira samoukidanje razlika. (Gajin 223)

Uzmemo li književnost kao ogledni uzorak kulturnoga i umjetničkoga stvaralaštva koje je regulirano ekonomijom industrijske shematizacije rada, tada spomenutu standardizaciju, princip formule i ponavljanje jasno vidimo u klasificiranosti teksta žanrovskom politikom, u tipiziranosti teksta repertoarom provjerenih klišeja, konvencija i ostalih komercijalnih formula te u diskurzivnoj organizaciji teksta mimetskim realizmom kao najrazumljivijm književnim jezikom za masovnu publiku, što su sve uporišni elementi estetskoga populizma da bi se čitatelju osigurala komocija komformističkog kretanja prepoznatljivom strukturom književnog djela, uz to homogeniziranog „mašnom“ smisla, odnosno fabularnom kauzalnošću i ostalim narativnim tehnikama reprezentiranja konzistentne i svrhovite slike svijeta (Kearney 13-16). ${ }^{1}$ Budući da se čitatelja u potpunosti kondicionira samo za takvu estetiku,

takvim se procesom ujedno pripremaju uvjeti navelikog recepcijskog otpora prema razlici, odnosno prema alternativnim i avangardnim poetičkim konceptima, kao i prema onim praksama koje destabiliziraju i denaturaliziraju konvencije dominirajućeg realizma kao poetike koja je u višestrukoj strukturalnoj i generičkoj vezi s kulturom kapitalizma. Štoviše, perpetuiranje takve politike sve do uspostavljanja institucionalne i kulturno omasovljene dominacije kao uvjeta za kapilarno i totalitetno širenje utjecaja dovodi do interiorizacije tih diktata u autorskim poetikama

\footnotetext{
${ }^{1} \mathrm{O}$ arhetipskim humanističkim vrijednostima priče usp. Kearney. Nasuprot Kearneyjevim stavovima da priče humaniziraju ljudsku egzistenciju davanjem narativnoga smisla te prevođenjem kontingentne zbilje u konzistentnu sliku koja čini svijet kognitivno preglednim, za kritiku manipulativnog, pa čak i opresivnog karaktera narativnog strukturiranja i fabriciranja zbilje usp. Ricoeur.. Ono što konvencionalnu priču čini zahvalnim diskurzivnim konceptom jest - kako to u jednom drugom kontekstu naziva Cvjetko Milanja - „dogmatizam smisla“ (12), odnosno ono što smo u ovom kontekstu ironično imenovali kič-slikom „mašne smisla“ nad sadržajem kako bi se heterogenost zbilje integrirala u ekonomičnu, a time i spoznajno shvatljivu interpretaciju, ma koliko ona bila reduktivna, no s ciljem da se „logiku priče predstavi kao logiku zbilje“ (Gajin 216).
} 
na način da se umjetnička sloboda više ni ne može misliti u drukčijim uvjetima. (Gajin 223-24)

Koje su praktične posljedice takvog razvoja situacije u svakodnevnom iskustvu književnika i koje su proporcije opresivnosti takvih naloga prema kreativnoj slobodi umjetničkoga stvaralaštva autobiografskom ispovijedi ilustrira Dubravka Ugrešić:

Moram pristati na standardizirani oblik komunikacije kako bi me moji potencijalni čitatelji (...) zaista čuli i nastavili sa mnom komunicirati. Jer ako je globalno tržište mcdonaldizirano, starbucksizirano, (...) onda nema razloga da se i druge ljudske djelatnosti - (...) film, televizija, književnost - ne ponašaju po istom tržišnom principu, kao megatočke standardizacije (...). Svi me (...) gurkaju (...) prema standardizaciji moje poruke. (224-25)

Represivnost tako uspostavljenog režima normativnog unificiranja kulturne proizvodnje do stupnja ovladavanja autorovom imaginacijom, estetskim stremljenjima umjetnosti općenito i razvojem ukusa među publikom Ugrešić ocjenjuje kulturno devastirajućima zbog rezultiranja masovnom količinom neinventivnih, konfekcijskih djela koje stoga ona generalno kvalificira kategorijom kiča. Jer,

izdavači su se već odavno okrenuli prema hipotetičnom ukusu većine potrošača, a ukus većine potrošača mnoge će knjige odbaciti kao „kulturno nerazumljive“ (...). I naš književni ukus, ukus književnih potrošača, s vremenom se standardizirao i prilagodio proizvodima koje nudi kulturna industrija (284)

pa „ako želi postati vidljivim, a svaki želi, autor se mora prilagođavati općem tonu, tonu prihvatljivom za zamišljeno opće uho“ (223). Konačnu ocjenu rezultno donosi Vilém Flusser: „Sva umetnost i duhovnost, moglo bi se zaključiti, ili će stupiti u službu tehničkog (...), ili se gase u smešnoj izolaciji takozvanog avangardizma“"(218).

\section{Otpori i kapitulacije dojučer nemjerljivih vrijednosti}

U kontekstu dosad rečenoga, Amazonova inicijativa logičan je nastavak opisanih tendencija kapitalističke ideologije prema daljnjem kooptiranju kulturne sfere i umjetničkoga stvaralaštva u ekonomski diktirani poredak, ali ujed- 
no predstavlja i simptomatični novi moment kojim se najavljuju nezamislive mogućnosti i budući standardi u ovladavanju i operiranju spektrom preostalih nesvodljivih vrijednosti iz simboličkog kapitala kulturno-umjetničkog stvaralaštva. Pri tome nije riječ samo o tome da plaćanje pisaca po broju pročitanih stranica predstavlja još jednu tipičnu praksu ove korporacije kao ionako prisutnu politiku u svim segmentima Amazonova poslovanja, i to ekstremnom provedbom taylorizma te ostalim eksploatacijskim mehanizmima kakve je Amazon do besramne brutalnosti oslobodio i razvio iz imanentne prirode kapitalizma, nego je također i izraz trajnog nastojanja kapitalističkog sustava da se razriješi frustracije zbog nemogućnosti da joj kriteriji ekonomske vrijednosti u potpunosti ovladaju „delatnostima čiji smisao nije u njihovom ekonomskom uspehu“ i „čija se produktivnost sadržinski postavlja sasvim s one strane ekonomskog kretanja“ (Simmel 335). Pa „budući da se ne mogu izraziti u jedinicama vrijednosti, njihovo vrednovanje kao kapitala ostaje problematično“ (Gorz 26).

Bez obzira na to do koje je mjere kapitalistički režim tijekom povijesti ipak uspio prisvojiti „neovisne aktivnosti čija se socijalna i/ili kulturna vrijednost ne može mjeriti rentabilnošću niti o njoj ovisiti“ (Gorz 20), uključujući i prostor umjetničkoga stvaranja, umjetničkom djelu uvijek u svome nukleusu i opsegu diseminacije preostaju kategorije vrijednosti koje izmiču ekonomskoj regulaciji, maksimalizaciji eksploatiranja i ostalim kapitalističkim ortodoksama te stoga, umjesto da budu u punom opsegu resurs akumulacije profita, predstavljaju mjesto provokacije, otpora i negacije tendenciji kapitalizma da „izvlači profit iz svih sposobnosti, kompetencija i resursa koje osobe razvijaju u svakodnevnom životu“ (Gorz 20). Adorno će umjetničko stvaranje definirati kao „onu vrstu prakse koja je s onu stranu okova rada“ (42) i istaknuti da joj je zadaća zbog nerazmjenljivog dijela svoje prirode biti kritika razmjenske vrijednosti u civilizaciji koja je univerzalizacijom ekonomskih odnosa učinila sve stvari razmjenjivima (153).

„Istinski izazov svim oblicima ekonomizma, književni poredak (...) predstavlja se kao naličje ekonomskog sveta: oni koji u njega ulaze imaju bezinteresni interes“, reći će Bourdieu (305). Simmel će problematiku novčane i ekonomske vrijednosti te pitanja razlika među kategorijama vrijednosti objasniti „na jednom primeru, koji je sasvim daleko od ekonomskih vrednosti, pa je upravo zato podoban za razjašnjavanje načelne strane tih vrednosti (...): na estetskom primeru“ (29). Gorz će i u umjetničkom stvaranju vidjeti „neunovčiva dobra koja imaju unutarnju vrijednost“ (21), dok će autori ulagati svoje „dostojanstvo“ u umjetničko stvaranje da bi izašli iz otuđenosti kapitalističkog rada, „da se spasi 
vlastita čast, da se 'sačuva vlastita duša'. Da bi dio svojeg života iščupali iz kandži posvemašnje uporabe rada“ (16). I za umjetnost vrijedi da bi, kako to kaže Robert Young, trebala „funkcionirati kao višak koji ekonomija ne može pojmiti“ (Readings 238), dok Nuccio Ordine zaključuje: upravo bi se književnost, imuna na težnju za profitom, mogla postaviti kao otpor egoizmu današnjice, kao protuotrov na tiraniju korisnoga (...). Njezino postojanje usmjerava našu pozornost (...) na vrijednosti koje idu usuprot struji (38).

Stoga se u kontekstu Ordineova spomena književne imunosti na težnju za profitom čini primitivnom i promašenom Amazonova odluka da uvede „cash nexus“ ili gotovinsku sponu ${ }^{2}$ anticipativno, već u fazi nastajanja teksta jer za očekivati je da će nezanemariv broj autora odbiti da im spisateljski impuls, estetiku i narativnu strukturu djela diktira „logika ograničene ili zatvorene ekonomije“ (Readings 352). I premda su se prve kritičke reakcije u medijima zadržale na ekonomskoj dimenziji problema (Kizer), gledajući na takvu Amazonovu politiku kao slučaj nepravedne raspodjele prihoda, a u konačnici i kao čistu pljačku onih autora čija su djela kompulzivno kupljena, a nikad pročitana, još je problematičnije što takav model regulacije znatnom preciznošću pooštrava razmjensku vrijednost umjetničkog djela, odnosno produbljuje eksploataciju nastalih vrijednosti u polju književnosti, umjetnosti i kulture zato što je, pojašnjava Gorz, kriza mjerljivosti tih vrijednosti dovodila do krize definiciju biti razmjenske vrijednosti te je onda vodila i do krize sustava ekvivalentnosti koji regulira robnu razmjenu (24).

Što god samim autorima značio ili ne značio novac u tako postavljenom odnosu, i koliko god takva Amazonova odluka bila rukovođena tipičnim kapitalističkim interesom za novčanom dobiti kao krajnjom svrhom cijele operacije, između toga novac obnaša još niz funkcija i proizvodi efekte koji su od paradigmatskog značaja za razumijevanje novog, rigoroznijeg stupnja kulturno-umjetničke podređenosti kapitalističkim „fantazmama efikasnosti, iskoristivosti, kontrole, vrhunske učinkovitosti i prilagođavanja" (Liessmann 74). Naime, novac se svojim apstraktnim, naizgled neutralnim statusom mjerne jedinice za utvrđivanje ekvivalentnosti afirmirao u idealni izraz razmjenske ekonomije, dok numeričkim predstavljanjem vrijednosti „relacije stvari izjednačava i tamo gde same stvari ne poseduju nikakvu jednakost ili sličnost" (Simmel

${ }^{2}$ „Cash nexus“ ili gotovinska spona je, kako prenosi Readings (18), ,svođenje svih ljudskih odnosa, osobito odnosa proizvodnje, na novčanu razmjenu; pojam se najčešće pojavljuje u tekstovima Karla Marxa“. 
128). I premda ima situacija kada, kaže Simmel, „roba i novac ne moraju biti međusobno merljivi“ (114), a u ovakvom slučaju Amazonova financijskog tretiranja književnoga teksta govorimo upravo o toj vrsti problematičnosti, novac je takvom Amazonovom „invencijom“ eksplicitno postavljen u relaciju spram knjiškoga teksta tako da „kvantitativna modifikacija jednoga daje indeks za kvantitativnu modifikaciju drugoga" (Simmel 115).

Novac je „izraz ili simbol modernog naglašavanja momenta kvantiteta“, kaže nadalje Simmel (295), odnosno temeljni izraz modernoga uma da racionalizira do potpune „objektivnosti“ sve odnose i identitete tako što ih prevodi u numeričku egzaktnost izmjerljivih vrijednosnih volumena da bi time kognitivno i operativno ostvario instrumentalizacijsku moć nad svijetom nad kojim vlada autoritetom matematičke logike, bez obzira na to provodi li se takva paradigma tehnoznanstvenim praksama ili ekonomskom regulacijom. Međutim, za takav se svijet „nemogućnost da se utvrde i standardiziraju svi parametri traženih davanja očituje u uzaludnim pokušajima da se kvantificira njihova kvalitativna dimenzija, a time i definicija normi učinka sračunatih gotovo na sekundu“ (Gorz 24) sve dok nije osvanula digitalna tehnologija, pruživši kapitalizmu uvjete da radikalizira taylorističku organizaciju i kontrolu rada, a povrh toga intenzivira racionalizaciju, kvantifikaciju, formalizaciju, propisivanje i regulaciju budući da se informatizacijom industrije svaki trenutak rada pretvara u upravljanje informacijama, pa se proces produktivnosti prati i mjeri parametrima ekvivalentnosti u numeričkim kvantitetama kao što, recimo, u realnom vremenu termometar prati i mjeri rast ili pad temperature. Pojavivši se kao „odgovor na potrebe modernog kapitalizma“ (Gere 19), digitalna infrastruktura unapređuje „klasifikaciju, uspostavljanje kategorija, određivanje proseka, utvrđivanje normi“ (40), tako da se sada i „svojstva kojima je nemoguće zapovijedati“ (Gorz 10) svode na „rad u svom neposrednom, mjerljivom i kvantitativno iskazivom obliku“ (7) s ciljem da „neopipljivi kapital profunkcionira kao kapital“ (40).

\section{Prijeteća infopolitika: kvantifikacija svakog poteza u temelju je društva kontrole}

Amazonov patent preciznog nadziranja i mjerenja donedavno jedne posve privatne i solističke aktivnosti kao što je čitanje knjige stranicu po stranicu te konzekventno operiranje tim podatkom tako što ga se prevodi u ekvivalentnu brojčanu vrijednost za daljnje interesne potrebe kapitalističke ideologije ne znači samo uvođenje i te djelatnosti u ekonomiju tržišnih odnosa nakon što je do sada 
precizno poznat broj pročitanih stranica kao osobni podatak bio nedostupan kapitalističkom nadzoru i konzekventnoj financijalizaciji čitateljskog čina, nego ujedno predstavlja i frapantno zadiranje tehnoznanstvene moći u trag, odnosno digitalni otisak autonomije „čitanja u sebi“ kao mjesta unutarnje slobode i kritičke svijesti. I ovime se, dakle, potvrđuju stajališta da je „kvantifikacija svakog poteza u temelju (...) društva kontrole“ (Vuković 207), odnosno da „suština tehnike nije ništa tehničko, već totalitarno" (Jovanović 15), tako da se i takve prakse kao što je Amazonova „tiču ne toliko puke informatike, koliko prijeteće infopolitike“ (16), dok će Liessmann dodati: „što su (...) automatizacijske tehnologije naprednije, tim se bolje mogu industrijalizirati kompleksnije djelatnosti sve tamo do područja individualnih sfera komunikacije, pa i same intimnosti“ (33).

Međutim, Liessmann ističe da se sinergijom između kapaciteta novih tehnologija u informacijskom praćenju rada i kapitalističkih apetita za maksimalizacijom efikasnosti rada uspostavlja paradigma reguliranja, nadziranja i discipliniranja čak i među onim djelatnostima i proizvodima koji svojim karakterom još uvijek izmiču kapitalističkoj politici materijalne ekonomije tako što se kvantificiranjem, rangiranjem, normiranjem te raznim drugim oblicima mjerenja i prevođenjem u numeričke vrijednosti „simulira tržište tamo gdje ono uopće ne postoji“ (68), odnosno prisustvo konstruiranog i arbitrarnog rangiranja samo potvrđuje da u područjima primjenjivanja takvih normirajućih, kvantificirajućih i evaluirajućih mehanizama kapitalizam, odnosno tržište kao „idealni“ regulator ne funkcionira. Kada govori o tom problemu, primarno je fokusiran na sveučilišta kao mjesta proizvodnje kognitivnog, simboličkog i spoznajnog kapitala te „ljudskih resursa“, odnosno kvalificirane radne snage za zahtjevne zadaće suvremenoga kapitalizma, a koje takvim režimom postaje mjesto gdje će se „znanje degradirati na prepoznatljivu brojku humanog kapitala s kojom je moguće računovodstveno raspolagati“ (9), pa zaključuje: „Od samog je početka misao o vrednovanju i rangiranju u korelaciji s paradigmom poslovno-ekonomskog mišljenja; ono je od škola i sveučilišta htjelo stvoriti poduzeća koja bi valjalo mjeriti prema njihovim tržišno usmjerenim rezultatima“ (69).

Iz tog je razloga u školskim učionicama i na sveučilišnim katedrama u tijeku „stvaranje proizvodnih brigada kojima se bez problema unaprijed mogu zadati ciljevi, stope rasta i izračuni iskoristivosti i u kojima ništa ne smeta toliko kao individualna odstupanja“(Liessmann 36), dok će Bill Readings u kritičkoj analizi suvremenog statusa, funkcije i misije visokog obrazovanja istražiti restrukturiranje sveučilišta u korporativni način rada, što uključuje čak i mjerenje ugleda 
(58-59). Borrero Cabal, prema Readingsu, za Sveučilište predlaže postupak stalne samoprocjene prema „pokazateljima učinka“ na temelju kojih procjenjujemo „kvalitetu, izvrsnost, učinkovitost i primjerenost“ (212). Svi su ti pojmovi, kako i sam priznaje, „preuzeti iz ekonomskog žargona“ te dopuštaju samoprocjenu Sveučilišta kao pitanje unutarnjeg i vanjskog računovodstva (Readings 70).

Tržišno vrednovanje sveučilišta i njegova simboličkog kapitala postaje identično „procjeni troškova i prednosti kupnje Honde Civic“ (Readings 62). Vratimo li se na područje umjetničke proizvodnje, identična logika vrednovanja događa se kada mediji u polemici između filmskoga redatelja Dalibora Matanića i influencerice Doris Stanković ${ }^{3}$ presude u korist dotične influencerice kao kulturnodruštveno vrednije jer je Matanićeve filmove „pogledalo malo više od 150 tisuća ljudi“, dok Stanković „na TikToku ima 250 tisuća pratitelja, na YouTubeu 107 tisuća pretplatnika, na Instagramu 78 tisuća pratitelja“ (Mazzocco), pa će takvom analitikom autor poantirati kako je Matanić „u usporedbi s utjecajem Doris Stanković potpuno beznačajan", tim više što je njegovo filmsko stvaralaštvo produkcijski skuplje, dok dotična influencerica nema gotovo nikakav trošak u svom poslu budući da svakodnevicu svoga lifestylea dokumentira mobitelom i potom transferira na društvene mreže, ostvarujući time komercijalno-marketinške efekte, precizno izračunate i evaluirane pobrojanom količinom publike.

I u ovom se slučaju vulgarizacije kulturnoga kapitala parametrima materijalne ekonomije, odnosno kapitalističke logike vrijednosti „otkriva (...) da postoje unutarnja bogatstva i da ih ekonomija koja poznaje samo robnu vrijednost dovodi do uništenja“ (Gorz 62). I ova je situacija

\footnotetext{
${ }^{3}$ Polemika se u javnosti razvila nakon što je influencerica Doris Stanković predložila osoblju prestižnog restorana da im ne plati pojedeni obrok, nego da ih reklamno preporuči s najvišim ocjenama na društvenim mrežama. Kritički komentari protiv Doris Stanković kretali su se u rasponu od osude jeftinog trika da bi se izbjeglo plaćanje cijene restoranske usluge, pa do generalnog ismijavanja mladih generacija koje ne razumiju ekonomske osnove svakodnevne egzistencije uslijed konfuzne percepcije životnih realiteta pod sve dominantnijim utjecajem virtualnoga koegzistiranja na novim medijima. Podržavatelji Doris Stanković svoju su obrambenu argumentaciju razvili do stupnja generacijskog jaza zbog kojega starija generacija ne razumije nove modele i prakse kapitalističke ekonomije u kulturi mreže i novih medija, dok su neki čak u postupku Doris Stanković vidjeli inventivnu antikapitalističku subverziju malog, pomoću medija demokratiziranog pojedinca protiv Golijata kapitalističkog sistema. Međutim, ponajviše reakcija izazvao je polemički odgovor redatelja Dalibora Matanića budući da je u svom kritičkom tekstu Doris Stanković osudio kao tipičan simbol novog naraštaja i generacijsku predstavnicu „lijene, neradničke bagre“ koja nikako da sazrije i počne privređivati za život tako što bi se konačno počela baviti ozbiljnim i korisnim poslovima.
} 
razotkrila teškoću kapitalizma da „nematerijalni kapital“ pretvori u (novčanu) vrijednost, da pokrene kapitalsko funkcioniranje te u biti nemjerljive, nerazmjenjive vrijednosti i da pokrene funkcioniranje „kognitivnog kapitalizma" kao kapitalizma. (Gorz 60)

Gorz nadalje ukazuje na paradoks da adekvatna ekvivalentnost simboličkog kapitala i njegove izračunljive protuvrijednosti uopće nije postignuta jer to nije ni moguće s obzirom na neizmjerljivi karakter kulturne proizvodnje i proizvedene „robe“ u kulturnosimboličkoj industriji, pa je upravo zato takva politika jednako i devastirajuća i frustrirajuća, ali cilj je ionako, kaže Gorz, da takve tendencije „odražavaju odnos snaga, ne odnose ekvivalentnosti“ (60).

U tom su smislu onda i jasne situacije u kojima kapitalizam demonstrira moć ne tako što proširuje eksploatacijske mehanizme u totalitetu, nad svakim djelom i nad svakim trenutkom kulturno-umjetničkog stvaralaštva kako bi maksimalizirao dobit ili barem vršio nadzor i regulaciju prema obrascima svoga sustava, nego tako što pojedine prakse odbacuje, odnosno marginalizira, isključuje, obezvrjeđuje i obesmišljava stavljanjem izvan svog klasifikacijskog sustava ili dodjeljivanjem nestimulativne vrijednosne ekvivalencije („Gdje počinje izvornost?"). Nad onim praksama koje su uvedene u sustav tako što ih se kontrolira i regulira standardizirajućim mjerenjima ili „stimulativnim“ pragovima vrednovanja moć kapitalističke logike materijalizira se anticipativnim samodiscipliniranjem autorskoga izraza, odnosno prilagođavanjem kreativnosti zadatoj strukturiranosti i pristajanjem na diskurzivnu kodifikaciju vladajućom paradigmom radi integracije, odnosno - kako to naziva Ugrešić - vidljivosti, što rezultira - kako to opet kaže Gorz - uništenjem na način da se potencijali i pluralizam kulturnoumjetničkog polja sistematski reduciraju na tvornički shematično perpetuiranje repertoara komercijalnih formula, poetički manifestirano unificiranim jezikom, stilskom homogenizacijom i estetikom istovjetnosti $(21,24,52,62)$.

Ali kako se s rastućim performansama kontinuirano napredujuće digitalne tehnologije u pravcu tehnoznanstvenog ideala ovladavanja i operiranja empirijskim svijetom, ali i ljudskim duhom metodom racionalističke, tehnokratske, univerzalne izmjerljivosti, odnosno pratliivosti kvantificiranih podataka, tako se Gorzovo „odražavanje odnosa snaga“ više ne ostvaruje na način da se logika robne ekonomije, tj. odnosi ekvivalentnosti koriste u prostoru nemjerljivih i nerazmjenjivih vrijednosti kao paradigmatski model, odnosno kao sistemski uzor 
tako što se konstruiranim analognim sustavom mjerenja i vrednovanja „simulira tržište tamo gdje ono uopće ne postoji“ (Liessmann 68), nego se konverzijom svih radnji i interakcija na digitalnu infrastrukturu konačno doista ekstenzivnije i intenzivnije ostvaruje ideal totaliteta $u$ industrijalizacijskoj ekonomizaciji funkcionalnosti i efikasnosti kroz rigorozniju kvantitativnu evaluaciju dosad „neopipljivih“ vrijednosti simboličkoga kapitala, kao i fluidnih, nemehaničkih, nadzoru lako izmičućih etapa stvaralačke procesualnosti u kulturi i umjetnosti.

\section{Netflixov model kontrole storytellinga i tabu spojlanja}

Amazonova penetracija u tkivo teksta i vršenje pritiska na strukturiranje teksta, a time i na kreativnu autorsku slobodu imaginiranja nedvojbeno predstavlja korak dalje u sve vidljivijim ambicijama da se uz pomoć tehnologijske moći novih digitalnih medija ovlada i logici ekonomskih zakona podredi, disciplinira i normira autora u stvaralačkim fazama prije nego što je umjetničko djelo uopće finalizirano, no ekonomskim interesima diktiran stvaralački proces i tehnologijom nadzirana kreativna sloboda autora već su integrirani u pripovjedne mehanizme i konstitutivni su čimbenici „estetskog“ identiteta suvremenih narativnih formi u ovome mileniju.

Osim što su autori tipičnom diskurzivnom politikom neoliberalnog kapitalizma imenovani kao „dobavljači sadržaja“, što njihovo stvaralaštvo svodi u kategoriju robnog resursa za daljnju eksploataciju i oplodnju kapitala, indikativan je pokazatelj naročite ekonomske fokusiranosti na interesno kapitaliziranje atrakcija pripovjednih praksi odnedavno uspostavljanje tabua tzv. spoilanja, kao da je vrijednost umjetničkoga djela isključivo u fabularnoj napetosti, nepredvidljivim obratima i iznenađujućim raspletima. No, za logiku ekonomskoga uma očito jest, videći u obrascima, konvencijama i klišejima narativnoga strukturiranja dovoljan repertoar formula za mehaničko reproduciranje formula zbog kojih ograničeno varirana identičnost takvih djela izaziva prepoznatljivost, stoga i popularnost, a na koncu i repecepcijski konformizam, čije se uživanje takve umjetnosti svodi na notorno konzumerističko trošenje atraktivne pseudonovosti još jedne eskapističke priče. ${ }^{4}$

\footnotetext{
${ }^{4}$ Christian Salmon elaborirat će tezu da interes kapitalističkog sustava prema storytellingu nije samo ekonomske naravi, s ciljem eksploatiranja i utrživanja pripovjednih atrakcija za potrebe industrije zabave, nego je i ideološki, s nakanom da se pomoću priča prikrije dehumanizacijska kriza neoliberalnog kapitalizma, ali i učinkovitije pridobije djelatnike za sustav koji zapravo sve gleda kroz brojke, tablice, statistiku, kvantifikaciju, prihode i troškove. „Mnogi (...) slave novi savez između kompanija
} 
„U ovom poslu cenzurira excel-tablica s podacima o strukturi publike“, reći će Vlado Bulić u razgovoru s Krunom Lokotarom za portal Kritika h,d,p, ukazujući tako na problem stvaralačke autokorekcije u razvijanju priče tijekom pisanja scenarija za televizijsku seriju sukladno povratnim informacijama o gledateljskim reakcijama kako bi se opstalo na hiperkonkurentnom tržištu priča. Bulićevo iskustvo je, dakako, primjer domaće, siromašnije verzije pokušavanja priključivanja svjetskim trendovima u industriji storytellinga, u kojoj ponajviše zabrinutosti za budućnost kreativnih sloboda izazivaju, dakako, Netflixovi algoritmi za precizno praćenje gledateljskih preferencija nad svakim aspektom fikcije, od tematike i fabularne dinamike preko žanrovskih i scenografskih rješenja, pa do tipologije likova i izbora glumaca. „Potencijalno je problematično pitanje kako oslanjanje na tehnologiju „velikih podataka“ (Big Data) može navesti umjetnički rad na određene, omeđene smjerove“, upozorit će Andrew Leonard („How Netflix is turning viewers into puppets“) u tekstu koji je u svoje vrijeme izazvao popriličan odjek zbog pesimističnih pretpostavki o pravcima razvijanja pripovjedne fikcije i autorskih sloboda koji bi u potpunosti bili dirigirani algoritamskim rezultatima praćenja recepcije. „Može li umjetnik (auteur) preživjeti u doba kada su računalni algoritmi krajnja fokusna skupina?" pita se Leonard, premda je zanimljivija argumentacija u reakciji na njegov tekst iz pera Josepha Blauera, koji ne razjašnjava svoj ključni, kategorični stav da se ljudskim ukusom nikada neće ovladati, niti će ga se moći izračunati, ni njime upravljati, smatrajući to podrazumijevajućim, ali zato će se potruditi objasniti o čemu je zapravo riječ i u čemu je nesporazum: u Leonardovu tekstu vidi strah od progresa, arhetipsku iracionalnost koja ima korijene - prema Blauerovu drastičnom datiranju - još od biblijske kazne zbog čovjekova posezanja za jabukom spoznaje. Zatim iz polemike miče budućnost kao kategoriju na koju uopće treba (pesimistično) misliti budući da podaci prikupljeni Netflixovim algoritmima „represents only the past“. Ali kako je jasno da se ti podaci aktivno koriste radi „sigurnije“ poslovne budućnosti, Blauer to relativizira retoričkim pitanjem ne radimo li to

i književnosti“, kaže Salmon: „Ljudi više ne žele informacije (...). Oni žele da veruju: u vas, u vaše ciljeve, u vaš uspeh, u priču koju pričate. Upravo vera pomera planine, a ne činjenice. (...) Dobar direktor kompanije mora da bude 'izuzetan pripovedač' (...). Umesto tabelarnih prikaza, poslovnih bilansa, operativnih rezultata, bolje bi bilo saradnicima i zaposlenima pripovedati priče. 'Osnovni posao menadžera jeste da motiviše zaposlene (...). Da bi se to postiglo, treba pokrenuti osećanja. Ključ za otvaranje srca jeste priča'“ (66-67). Ukratko, Salmonova teza je da kapitalizam na takav način uvodi iracionalnost kao strategiju ostvarivanja konsenzusa upravo u trenutku kada je neoliberalni kapitalizam postao bešćutno racionalan. 
svi, koristeći se empirijskim znanjem i iskustvom kao skupom podataka i kao kapitalom da bismo u budućnost zakoračili pametnije?

$\mathrm{Na}$ koncu, sluteći da takve operacije impliciraju krajnju dehumanizaciju, Blauer ublažava problem retoričkim vraćanjem humanog subjekta u sporne odnose, dok numeričke i podatkovne analize svodi tek na dimenziju pukoga uporabnoga instrumenta za unapređivanje kvalitete, zašućujući u onom trenutku kada se logično nameće progovaranje o instrumentalnoj podređenosti svih sudionika i cjelokupnog procesa u tim odnosima moći ekonomskim interesima kapitalističke ideologije tako što se svaki aspekt i svaki odnos prevodi u kvantitetu podataka radi statističke obradivosti iz kojih će se izlučiti zakonitosti kao poluge potpuno kontroliranog upravljanja ekonomskim rizicima umjetničke proizvodnje, odnosno do jučer više-manje nepredvidljvim učincima za kapitalizaciju investicije u umjetničkom stvaralaštvu na putu od autorskoga kreiranja do recepcije.

Ali nisu algoritmi fokusna skupina, nego mi. Mi smo ono što algoritmi nastoje obuhvatiti i pretvoriti u brojeve. Pritom nas se ne svodi na puke brojeve, nego se brojevi rabe kako bi nas se što bolje razumjelo. To govori o našoj vrijednosti,

slatkorječivo zbori Blauer, podilazeći nam spretnim preokretanjem naše „izračunljivosti“ $i$ isprogramiranosti cjelokupnoga procesa u nadređeni položaj nad „pukim“ servisnim pogonom za naše želje, potrebe, pa čak i za naš ukus. Za Blauera tako korištena tehnologija posve je „uobičajen“ i „svakidašnji“ postupak od pamtivijeka, „zastrašujućc samo po tome što je nov, progresivan, sofisticiraniji i učinkovitiji. Jasno, pozicirajući nas retoričkim strategijama u centar procesa, Blauer nas uvjerava da kontroliramo i razuvjerava nas da smo kontrolirani, no kritičari takve Netflixove prakse s razlogom nisu naivni, nego s popriličnom opreznošću i bojaznima analiziraju novopojavljene neravnoteže u odnosima moći koje kapitalistička ideologija u sprezi s mogućnostima novih tehnologija demonstrira na primjeru Netflixa kao svojevrsnom vjesniku budućih trendova i potencijalno nove kulturne paradigme.

Uostalom, znakovite su prve posljedice koje je registrirala Mareike Jenner u studiji Netflix and the Re-invention of Television, zamijetivši da je Netflix upravo uporabom spornih algoritama korigirao svoju produkciju tako što se iz početne produkcijske i scenarističke faze, faze koja ga je etablirala kao inovativnu, originalnu, provokativnu i revolucionarnu produkcijsku kuću na planu pripo- 
vjednoga umijeća i pripovjedne estetike u žanru televizijskih serija, sve više u narativnoj organizaciji svojih serija sužavao na generičke strukture, ponajviše kada je riječ o žanrovskoj konvencionalnosti, dok je ukupnu umjetničku kvalitetu usmjerio k estetskom populizmu, opredjeljujući se za provjeren repertoar komercijalnih formula i ostala rješenja popularizacije kojima se osigurava masovna recepcijska prihvaćenost (131-34, 139-60).

Premda se Jenner slaže s Blauerom kada kaže da „personal taste can be higly unstable and complex and dependent on circumstances beyond the knowledge of the algorithm“ (131), ipak ju zabrinjava utjecaj na autorstvo s obzirom na to da je Netflix uspio ,in expanding the calculable terrain, declaring that complex cultural concepts like lightness or darkness of a film's humor can be quantified“ (133), koristeći se, između ostaloga, „36-page training document that teaches (...) how to rate movies“ (132), tako da Netflixovi analitičari „capture dozens of different movie attributes. They even rate the moral status of characters" (132).

\section{Prema zaključku: vrli novi svijet dobavljača sadržaja}

I dok se spomenuti autori bave spekulacijama kakva bi mogla biti budućnost kreativnih sloboda, vrlo jasnu ilustraciju praktičnih posljedica takvoga modela poslovanja možemo već naći u potezima domaće gamerske tvrtke Nanobit, koja je izniman financijski uspjeh ostvarila profiliravši se u niši proizvođenja kompleksno narativiziranih soft erotskih igrica za žene otkrivanjem dobitne formule u kombinaciji romantičnih klišeja i meke pornografije. U reportaži o tvrtki Nanobit, nakon što je prezentiran uspjeh njihova projekta My Story, nadalje se navodi:

Očito je bilo da to treba dalje razraditi, naći dobitnu kombinaciju, kao i da im treba više priča. Preko portala Moj posao angažirali su tada profesionalne hrvatske pisce koji su im sami predložili i napisali neke drame i krimiće, ali to jednostavno nije prolazilo. „Bilo je lijepo napisano, ali te se knjige nisu čitale i obrisali smo ih iz biblioteke", kaže (Zoran Vučinić, jedan od osnivača kompanije, op. a.). (Grgas 49)

Zapazivši u kojem se pravcu povećava korisnički interes, Nanobit je angažirao 20-ak anonimnih američkih autora kojima šalju sinopsis osnovnih pripovjednih ideja da bi razradili scenarije prema povratnim informacijama dobivenih algoritamskim praćenjem korisnika: 
Ostalo je... kratka povijest intenzivnog razvoja i vratolomnog uspjeha u privlačenju i zadržavanju milijuna i milijuna igrača, gdje se uz pomoć tehnologije, praćenja ponašanja igrača, detektiraju nezanimljiva mjesta u pričama, ona gdje igrači odustaju od čitanja, i onda dopunjavaju atraktivnijim izborima, novim poglavljima. „Imamo svoj odjel analitike i sustav testiranja novih igara, a mjerimo i kako performaju kada ih mijenjamo. Zahvaljujući toj analitici naši urednici mogu smišljati nova rješenja i davati naputke piscima, uklanjaju se tzv. uska grla i igra se na kraju bolje monetizira", tumači Vučinić. U tom trenutku postaje nam jasnije kako su se to njihovi ljubići u nastavcima pretvorili u tolike dolare. Iza naizgled jednostavnih priča stoje složeni grafikoni, praćenje i analiza podataka, te precizno, targetirano modeliranje sadržaja kako bi igrači bili zadovoljni, ali istodobno i motivirani da troše novac. (Grgas 49)

Znakovit je korišteni vokabular u Vučinićevim izjavama i novinarkinim komentarima, ponajviše kada je riječ o egzekuciji „nezanimljivih mjesta“ $i$ „,uskih grla“, kao i neskriveni ton fasciniranog oduševljenja tehnologijom kontrole i uspjehom „monetiziranja“ u „tolike dolare“, dok je nadasve simptomatična prirodnost kojom se prezentira takva praksa i opsezi praćenja korisnika.

Reportaža nam, na žalost, ne najavljuje obrise prijeteće tehnoindustrijalizacijske budućnosti u kojoj će umjetnost pripovijedanja i autorska individualnost završiti prema željama i diktatima kapitalističke mašine, nego se ona ostvaruje i uvećava kao aktualna praksa naše današnjice i sve prihvaćeniji model naše budućnosti za kreativne (ne)slobode, posve utjelovljena u liku i djelu 24-godišnje književnice Anne Todd, koja je u potpunosti integrirala i interiorizirala takvu produkcijsku logiku u politiku svoga spisateljstva te u svoj autorski identitet, ostvarivši ogroman (financijski) uspjeh pisanjem svoga romana na platformi Wattpad, karakterističnoj po kontinuiranoj interakciji s čitateljima. „Sve je bilo podložno izmjenama ukoliko bi poklonici reagirali negativno“, navodi Nenad Polimac (29) i tako se iz te modernije verzije kolektivne književnosti kalio bestseller, manje strukturiran umjetničkom logikom i autorskom estetskom ekspresijom, a više konzumerističko-komercijalnim udovoljavanjem publici.

S obzirom na takav razvoj, nema potrebe da sanjamo dan kada će umjetna inteligencija pisati romane kada su živi autori ionako uspješno robotizirani, a imaginacija fiskalizirana. 


\section{Literatura}

Adorno, Theodor W. [Adorno, Teodor]. Estetička teorija. Preveo Kasim Prohić, Nolit, 1979. Bačić, Mašenjka. „Sud protiv Amazona.“ Novosti, 29. travnja 2020, https://www.portalnovosti.com/sud-protiv-amazona. Pristupljeno 10. listopada 2020.

Blauer, Joseph. „There’s no accounting for taste.“ Havas Montréal, 20. kolovoza. 2013, https:// $\mathrm{mtl}$.havas.com/en/insights/netflix-house-of-cards-data-2013/. Pristupljeno 10. listopada 2020.

Bourdieu, Pierre. [Burdije, Pjer]. Pravila umetnosti. Preveo Vladimir Kapor, et al., Svetovi, 2003.

Crnobrnja, Stanko. Estetika televizije i novih medija. Clio, 2010.

Erceg, Tena. „Hegemon Amazon.“ Novosti, 2. rujna 2018, https://www.portalnovosti.com/ hegemon-amazon. Pristupljeno 10. listopada 2020.

Flusser, Vilém. [Fluser, Vilem]. Komunikologija. Prevela Aleksandra Kostić, Fakultet za medije i komunikacije, 2015.

Gajin, Igor. Lelek tranzicije. Disput, 2020.

Gere, Charlie. [Gir, Čarli]. Digitalna kultura. Preveo Aleksandar Luj Todorović, Clio, 2011.

Gorz, André. Nematerijalni rad. Preveo Rade Kalanj, TIM press, 2015.

Grgas, Gordana. „Nanobit - kako su ljubićima osvojili urbane žene Amerike.“ Jutarnji list, 3. listopada 2020, br. 7951, str. 32-49.

Jenner, Mareike. Netflix and the Re-invetion of Television. Palgrave Macmillan, 2018.

Jovanović, Bojan. Digitalna despotija. Nova knjiga, 2008.

„Kad kultura postane biznis: Amazon će plaćati pisce po broju pročitanih stranica.“ Bankar. 2015. https://www.bankar.me/2015/06/27/kad-kultura-postane-biznis-amazon-ce-placati-pisce-po-broju-procitanih-stranica/. Pristupljeno 10. listopada 2020.

Kearney, Richard. O pričama. Prevela Martina Čičin-Šain, Jesenski i Turk, 2009.

Kizer, Chloe. „Amazon KDP \& Kindle Unlimited: What It Means for Authors and Publishers.“ Written Word Media, 21. kolovoza 2019, https://www.writtenwordmedia.com/ amazon-kdp-kindle-unlimited/. Pristupljeno 10. listopada 2020.

Leonard, Andrew. „How Netflix is turning viewers into puppets.“ Salon, 1. veljače 2013, https://www.salon.com/2013/02/01/how_netflix_is_turning_viewers_into_puppets/. Pristupljeno 10. listopada 2020.

Liessmann, Konrad Paul. Teorija neobrazovanosti. Preveo Sead Muhamedagić, Jesenski i Turk, 2008.

Lokotar, Kruno. „Razgovor: Vlado Bulić. U ovom poslu cenzurira excel-tablica s podacima o strukturi publike. "Kritika h, d, p, 10. kolovoza 2020, https://kritika-hdp.hr/hr/ razgovor/u-ovom-poslu-cenzurira-excel-tablica-s-podacima-o-strukturi-publike. Pristupljeno 10. listopada 2020.

Mazzocco, Vojislav. „Mataniću su šljam oni koji traže ručak za reklamu. Njegove se plaćaju i našim novcem. “Index.hr, 1. rujna 2020, https://www.index.hr/vijesti/clanak/ 
matanic-je-curu-koja-zica-veceru-nazvao-sljamom-on-je-uzicao-milijune-nasih-kuna/2209378.aspx. Pristupljeno 10. listopada 2020.

Medak, Tomislav i Marcell Mars. „Amazon.com: Anatomija jedne dominacije.“ Bilten, 31. srpnja 2019, https://www.bilten.org/?p=28562. Pristupljeno 10. listopada 2020.

Milanja, Cvjetko. Doba razlika. Stvarnost, 1991.

Okrugli stol. „Gdje počinje izvornost? Kategorizacija radova u humanističkim znanostima.“ Umjetnost riječi, br. 2, 2014, str. 243-74.

Ordine, Nuccio. Korisnost beskorisnog. Preveo Tony Šercer, Meandarmedia, 2019.

Polimac, Nenad. „Film koji je potukao sve glavne hitove.“ Jutarnji list, 8. listopada 2020, br. 7956, str. 28-29.

Readings, Bill. Sveučilište u ruševinama. Prevela Nevena Erak, Meandarmedia, 2016.

Ricoeur, Paul. [Riker, Pol]. Vreme i priča. Preveli Slavica Miletić i Ana Moralić, Izdavačka knjižarnica Zorana Stojanovića, 1993.

Salmon, Christian. [Salmon, Kristijan]. Storytelling ili pričam ti priču. Preveli Iva Brdar i Tijana Stamenković, Clio, 2010.

Semuels, Alana. „Amazon's Kindle Unlimited Is a Boon for Some Authors.“ The Atlantic, 20. srpnja 2018, https://www.theatlantic.com/technology/archive/2018/07/amazon-kindle-unlimited-self-publishing/565664/. Pristupljeno 10. listopada 2020.

Simmel, Georg. [Zimel, Georg]. Filozofija novca. Prevela Olga Kostrešević, Izdavačka knjižarnica Zorana Stojanovića, 2004.

Ugrešić, Dubravka. Europa u sepiji. Profil, 2014.

Vuković, Katarina Peović. Mediji i kultura. Jesenski i Turk, 2012. 


\title{
NARRATION OR STORY AS AN INSTRUMENT OR KNOT OF (DE)HUMANIZATION OR ...
}

\author{
Abstract \\ Igor GAJIN \\ Josip Juraj Strossmayer University of Osijek \\ The Academy of Arts and Culture \\ Ulica kralja Petra Svačića 1/F \\ HR - 31000 Osijek \\ gajinigor@gmail.com
}

In science and humanistic teaching, the precedence of quantification, measurability, bureaucratic content organization, and neopositivism - neo in terms of statistical data processing - is increasingly visible. It evidently follows the logic of a computerized presentation of information (instead of knowledge), and thus the capitalist disciplining and controlling of Gorz's "intangible labor." With the Internet, network philosophy, hypertext, and hyperinformation overload, a fragmented, dispersed, and decontextualized digital culture invokes in both theory and practice an oppositional reaction towards reaffirming the classic story or storytelling as an archetypal form of humanizing, organizing, and conceiving human experience and knowledge. However, when Amazon announces that the author will be paid an amount corresponding to the amount of pages of his text that are read through apps for tracking such results, when Christian Salmon discovers storytelling as a new instrument of corporate business, when storytelling becomes an imperative of commercial literature and a means of industrialized standardization of literature, all facilitated by the trend of creative writing workshops, the question is to whom and to what purpose the story serves today. Was the last century's (post)modernist deconstruction of the text and the disintegration of its ideologized meaning not as humane as it was unreadable, as opposed to today's seduction of the consumerist object through fabrications from the pen of "content providers"?

Keywords: digitalization, STEM, storytelling, postmodernism, capitalism 